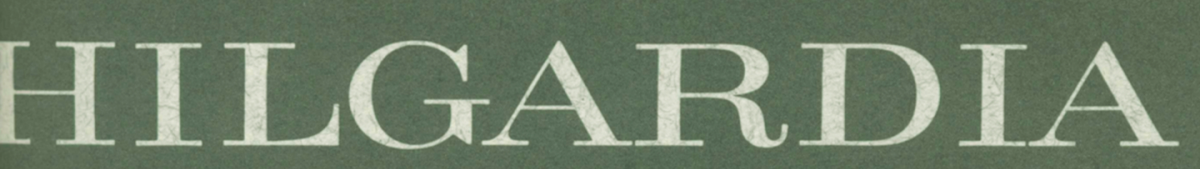

JOURNAL OF AGRICULTURAL SCIENCE PUBLISHED BY HE CALIFORNIA AGRICULTURAL EXPERIMENT STATION

Volume 35, Number $17 \cdot J u l y, 1964$

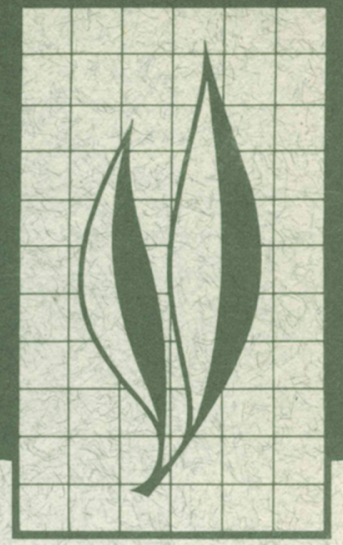

\title{
Water Movement Through Panoche Clay Loam Soil
}

D. R. Nielsen, J. M. Davidson, J. W. Biggar, and R. J. Miller 


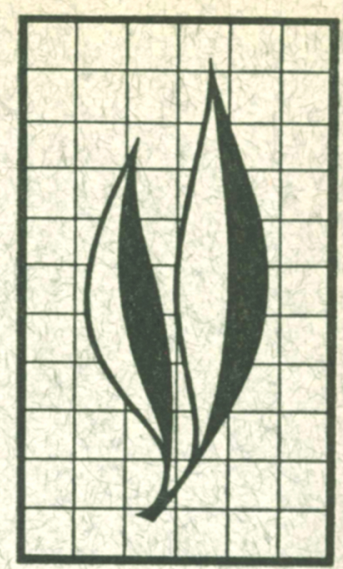

Water movement through Panoche clay loam is explained on the basis of the soil-water properties within the profile. Laboratorydetermined soil water content-tension relations from 3-inch cores taken from the field every 6 inches to 5 feet were shown to provide reliable estimates of soil water behavior. Water management practices relative to favorable plant-available soil water and favorable salt balance within the profile are discussed.

\section{THE AUTHORS:}

D. R. Nielsen is Associate Professor of Irrigation and Associate Irrigationist, Department of Irrigation, Davis; J. M. Davidson is Laboratory Technician, Davis; J. W. Biggar is Associate Irrigationist and Lecturer, Davis; and R. J. Miller is Assistant Irrigationist, Five Points. 


\section{Water Movement Through Panoche Clay Loam Soil ${ }^{1,2}$}

\section{INTRODUCTION}

This investigation involves the surface application of a known quantity of irrigation water to a field plot protected from evaporation and shaded from the sun. Frequent measurements of soilwater content and soil-water tension were made during infiltration and during a 2-week period following infiltration. Capillary conductivity values for seven soil depths were calculated from the field data. The observed water movement is discussed in relation to the physical properties of the soil profile.

Many investigations have been made for the purpose of measuring the amount of water stored in field soils after being wetted. Some bare fallow plots studied were either mulched or nonmulched, while other plots were covered with growing crops. Measurements of soil water were generally made by gravimetric sampling.

Of equal concern to the investigator have been the hydraulic gradients within the profile during and following infiltration. Although numerous methods have been used to measure the soilwater tension, and hence the hydraulic gradient, the most common and satisfactory measurements have been made with tensiometers. Some experiments have involved measurements of tension only, while others have included corresponding changes in soil water content.

Investigations by Israelsen [1918], Israelsen and West [1922], Scofield and Wright [1928], and Edlefsen and Bodman [1941] typify early endeavors to ascertain the water-storage capacity of soils. Soil water was measured gravimetrically in field plots before and after heavy irrigations. In addition to the quantity of water stored, the amount of water passing through soil profiles during extended periods of drainage was measured. In the case of the latter investigation it was found that the average rate of water lost from a 5-foot profile over a period of 2 days after irrigation to 30 days after irrigation was approximately 0.1 inch per day.

Using a neutron meter to measure soil water repeatedly at the same depths within several field profiles, Burrows and Kirkham [1958] studied the redistribution of applied water under the action of gravity to define field capacity. The field capacity of each 6-inch layer to a depth of 5 feet was defined on the basis of the shape of the drainage curves.

\footnotetext{
${ }^{2}$ Submitted for publication August 26, 1963.

2 This research was supported in part by funds from Research Grant No. DA-AMC-36-03963-G5 for the Army Electronics R \& D Activity, Fort Huachuca, Arizona.

"See "Literature Cited" for citations referred to in the text by author and date.
} 
Using a similar field technique, Nielsen et al. [1959] measured the amount of water stored temporarily above field capacity and explained the water movement on the basis of laboratory determinations of soil-water properties.

Tensiometers have been used extensively to study water movement through field soils [e.g., Cannel and Stolzy, 1962; Haise et al., 1955; Marshall and Stirk, 1949; Richards, 1954; Richards and Neal, 1936]. In these investigations, their use was primarily directed toward measuring hydraulic gradients existing during infiltration or during short periods of drainage following infiltration. In most cases, rates of water movement were inferred by using the Darcy equation. Soil layers responsible for restricted water movement were readily identified, although values of capillary conductivity could not generally be calculated owing to lack of information regarding water content changes.

Field estimates of capillary conductivity were made by Richards et al. [1956] and Ogata and Richards [1957] using tensiometer and gravimetric water content data. Measurements were made in the surface $50 \mathrm{~cm}$ of a sandy loam after a heavy irrigation. Surface evaporation was prevented in this latter study. Their data indicate that measurements were made seven or eight times during a 2-month period. The physical processes determining water loss from soil were discussed relative to the capillary conductivity values presented together with the migration of $\mathrm{KCl}$ added in the irrigation water. Other investigations designed to calculate the capillary conductivity of specific soil depths in situ are unknown to the authors.

Laboratory-determined values of capillary conductivity have been used to calculate or predict water movement in field soils [e.g., Green et al., 1964; Miller and Bunger, 1963; Nielsen et al., 1961]. Miller and Bunger [1963] used both tensiometers and a neutron meter to determine water content-tension-time relations at several depths within natural and artificially produced layered soils. Nielsen et al. [1961] predicted soil water infiltration profiles for two somewhat homogeneous field soils. Calculations were based on the analysis of Philip [1955, 1957]. Green et al. [1964], using laboratory-determined values of capillary conductivity and a high speed computer, predicted water movement in naturally-layered soils. In each of these three investigations, the calculated soilwater profiles were in general agreement with those measured, although several discrepancies were apparent.

It is the purpose of this investigation to evaluate soil water movement through Panoche clay loam and relate the movement to physical processes involved and certain properties of the soil measured in the field and laboratory.

\section{EXPERIMENTAL PROCEDURE}

The experimental plot was located at the West Side Field Station of the University of California 40 miles southwest of Fresno. The plot was located in the SW $1 / 4$ of the NE1/4 of Section 27, T. 18S., R. 17E. on a soil classified as Panoche clay loam. A typical description is given in the Appendix of this publication.

The plot used was part of an irrigated field on which grain had been grown for several years. It consisted of a level, square area 12 feet $\times 12$ feet which was surrounded and defined by a low earth dike. The plot was undisturbed by the construction of the dike with inner faces consisting of $2 \times 12$-inch boards set on edge. An area 4 feet $\times 4$ feet in the middle of the plot was chosen for analyzing soil water movement. Thus, a guard strip 4 feet wide surrounded the sampling site. Outside the plot, the soil water content was not excessively low, as evidenced by tensiometer readings. 
Four mercury-in-glass tensiometers were located at each of the following depths: $6,12,18,24,30,36,48$ and 60 inches. Four 1.5-inch diameter thinwalled aluminum access tubes were placed 6 feet into the soil. Water content measurements were made at 6 -inch intervals from the 6 -inch to the 5 -foot depth.

Prior to measurement of water content, a first-wetting and drainage period was initiated by adding to the plot enough water to wet the soil well below 5 feet. Two weeks later the soil was similarly wetted and a second drainage period initiated which lasted 2 weeks. During the two drainage periods the tensiometers performed satisfactorily. The water content and the soil-water tension throughout the 5-foot soil profile were measured and recorded at the end of the second drainage period.

At the end of the second drainage period, and after the water contents had been measured, increments of water totaling 4.8 inches were applied at less than a 1-inch head above the soil surface during infiltration. The last increment of water to seep through the soil surface corresponded exactly to 24 hours after infiltration was initiated. The rate at which the water infiltrated into the surface was measured by means of a hook gauge. The entry rate was greatest when the water was first applied and diminished to a virtually constant rate near the end of the 24-hour infiltration period.

After infiltration, and at the beginning of the third and final drainage period, the plot was covered with 4-mil (0.004 inch) black polyethylene film. A 1-inch layer of loose top soil was spread evenly over the polyethylene cover. During the course of the experi- ment the plot was shaded by a light canvas canopy constructed 8 feet above the plot.

During infiltration and the first 24 hours of drainage, soil-water tension and content were recorded at approximately 30 -minute intervals; these measurements were made less frequently during the succeeding 2 weeks. The mean values of the four measurements taken at each depth were plotted against time. From these curves, the rate at which water passes any particular depth was known as a function of time. In addition, the soil-water tension gradients and the average water contents from which the capillary conductivity relations could be calculated were available.

Several days after the last water measurements had been made a pit was dug where measurements had been made, and core samples 3 inches in diameter and 3 inches high were taken at 6 -inch depth intervals to 6 feet. In addition, core samples were removed from the same depths in four other pits dug close to the experimental plot. Water content versus tension curves (soil characteristic curves) were measured on these samples, using fritted glass bead plates described previously [Nielsen and Phillips, 1958]. Tensions used for defining the curves were $2,17,32,47,62$, $82,102,122,152$, and $300 \mathrm{~cm}$ of water. From the oven-dried weights of these samples, bulk density values were obtained. From other samples taken at the above mentioned depths, soil characteristies were ascertained using pressure plate and pressure membrane apparatuses [Richards, 1947, 1949] with pressures of $0.1,0.33,0.5,1.0,2.0,5.0$ and 15.0 bars. Particle-size distributions were measured also [Bouyoueos, 1951].

\section{RESULTS}

The following is the chemical analysis of the station's well water used in this study: $1.35 \mathrm{me} / \mathrm{l}$ Ca, $1.00 \mathrm{me} / \mathrm{l} \mathrm{Mg}, 8.26$ $\mathrm{me} / \mathrm{l} \mathrm{Na}, 0.03 \mathrm{me} / \mathrm{l} \mathrm{K}, 3.34 \mathrm{me} / \mathrm{l} \mathrm{Cl}$, $5.56 \mathrm{me} / \mathrm{l} \mathrm{SO}, 1.98 \mathrm{me} / \mathrm{l} \mathrm{HCO}_{3}, \mathrm{O} \mathrm{me} / \mathrm{l}$ $\mathrm{C}^{\mathrm{C}} \mathrm{O}_{3}$, and $1.4 \mathrm{ppm} \mathrm{B}$. The pII and the 
TABLE 1

PARTICLE-SIZE DISTRIBUTION AND BULK DENSITY VALUES

FOR PANOCHE CLAY LOAM

\begin{tabular}{|c|c|c|c|c|c|}
\hline Depth & Sand & Silt & Clay & Texture & Bulk density \\
\hline inches & per cent & per cent & per cent & & $\mathrm{gm} / \mathrm{cm}^{3}$ \\
\hline $6 \ldots \ldots \ldots \ldots+\cdots \cdots \cdots \cdots \cdots$ & 31.3 & 28.8 & 39.9 & clay loam & 1.47 \\
\hline $12 \ldots \ldots \ldots \ldots \ldots \ldots$ & 39.7 & 24.0 & 36.3 & clay loam & 1.45 \\
\hline $18 \ldots \ldots \ldots \ldots \ldots \ldots \ldots \ldots \ldots \ldots$ & 41.3 & 24.9 & 33.8 & clay loam & 1.34 \\
\hline 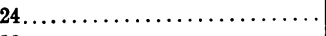 & 29.5 & 30.6 & 39.9 & clay loam & 1.29 \\
\hline 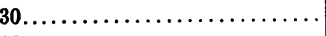 & 31.7 & 33.2 & 35.1 & clay loam & 1.19 \\
\hline $36 \ldots \ldots \ldots \ldots \ldots \ldots \ldots \ldots \ldots \ldots \ldots$ & 33.2 & 31.3 & 35.5 & clay loam & 1.31 \\
\hline $42 \ldots \ldots \ldots \ldots \ldots \ldots \ldots$ & 14.8 & 44.7 & 40.5 & silty clay & 1.21 \\
\hline $48 \ldots \ldots \ldots \ldots \ldots \ldots \ldots \ldots \ldots \ldots$ & 9.6 & 50.6 & 39.8 & silty clay & 1.25 \\
\hline $54 \ldots \ldots \ldots \ldots \ldots \ldots \ldots \ldots \ldots$ & 19.4 & 42.7 & 37.9 & silty clay loam & 1.26 \\
\hline $60 \ldots \ldots \ldots \ldots \ldots \ldots \ldots \ldots \ldots \ldots \ldots \ldots$ & 13.4 & 44.3 & 42.3 & silty clay & 1.31 \\
\hline
\end{tabular}

electrical conductivity of the soil extract were 8.3 and $1.13 \times 10^{-3} \mathrm{mmho} / \mathrm{cm}$, respectively.

Table 1 gives the particle-size distribution within the soil profile. The top 3 feet of the profile is predominantly a clay loam grading into a silty clay from the 3 to 5 -foot depth. The range of percentage of clay is 10 per cent, while that of silt and sand is 26 and 31 per cent, respectively. Soil bulk density was 1.47 $\mathrm{gm} / \mathrm{cm}^{3}$ at the 6 -inch depth; this value decreased with depth to a minimum at 30 inches, with the lower portion of the profile having an average density of about $1.25 \mathrm{gm} / \mathrm{cm}^{3}$. There appears to be no relation between soil texture and bulk density. Although this soil must be considered nonhomogeneous with respect to measurements made at the various depths, natural variations measured are not unlike the vast majority of many soils.

A smooth curve of soil-water tension versus time was obtained for each depth at which the tensiometers were placed. Figure 1 gives an example of these values for the 12-inch depth during the

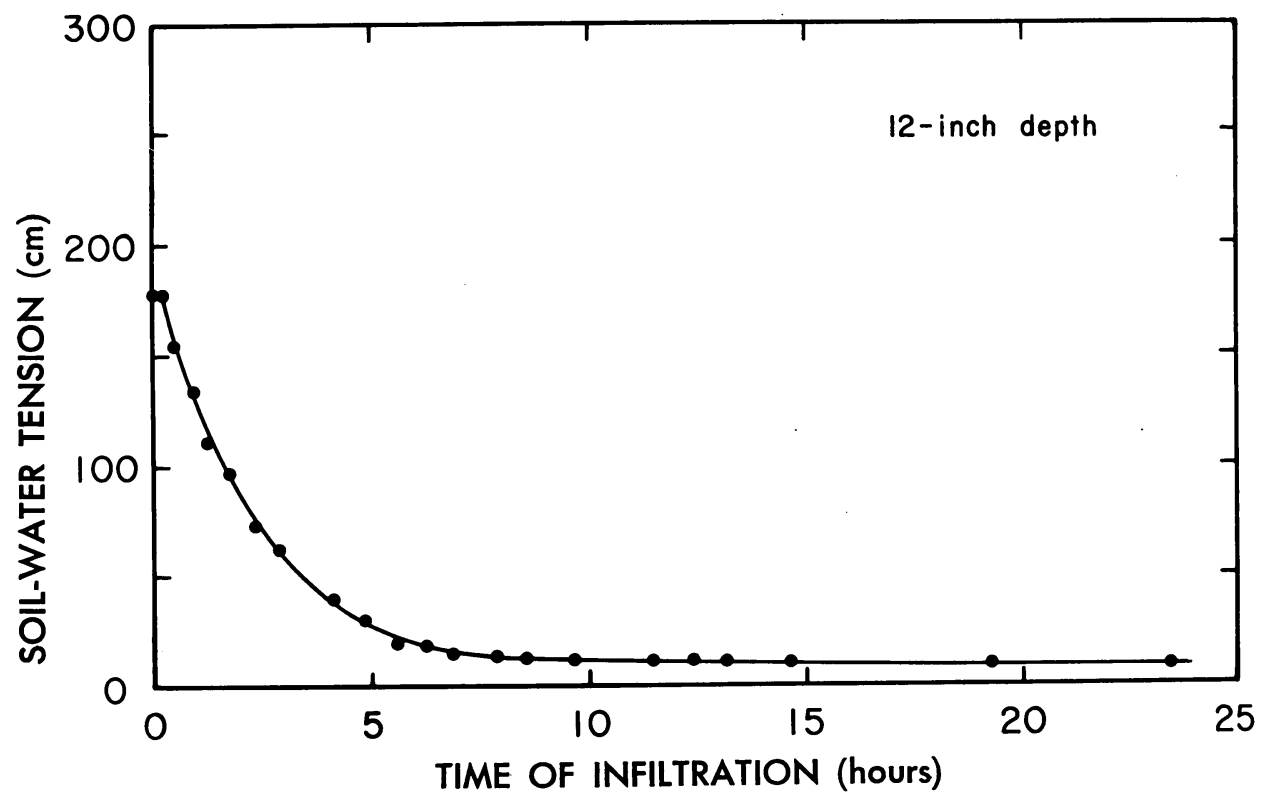

Fig. 1. Soil-water tension (cm of water) versus time of infiltration for 12-inch depth of Panoche clay loam as measured in the field. Each datum point represents an average of four tensiometer readings. 
24-hour infiltration period. Equally well defined curves were obtained for the other depths during the infiltration period and throughout the third 2-week observation period of drainage. From these series of graphs, the soil-water tension versus soil depth was plotted with time as the parameter. Figure 2 shows tension distribution throughout the profile for infiltration. During the first hour of infiltration the tensions in

SOIL-WATER TENSION $(\mathrm{cm})$

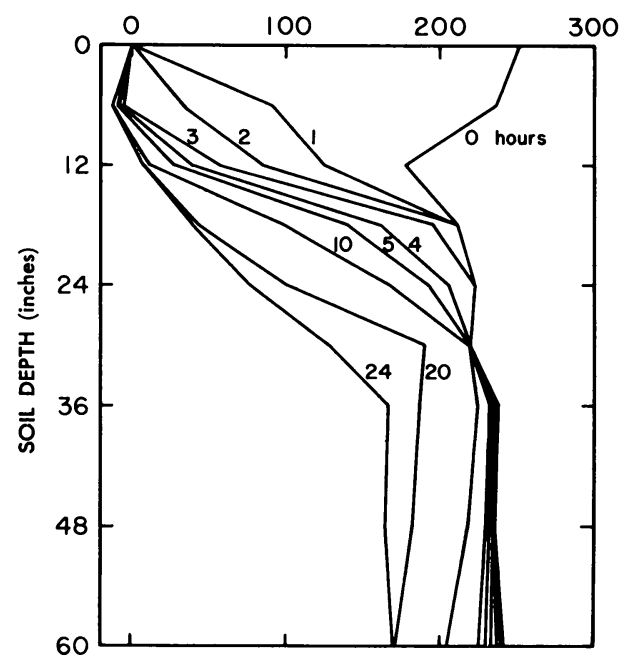

Fig. 2. Soil-water tension (cm of water) versus soil depth measured at $0,1,2,3,4,5,10$, 20, 24 hours after commencement of infiltration into Panoche clay loam. Zero hour designates initial tension distribution after the second drainage immediately preceding infiltration. Twenty-four hours designates tension distribution at end of infiltration and the beginning of the third drainage period.

the top one foot of soil changed markedly, while those from 18 to 30 inches remained unchanged. During the first 10-hour period, tensions below 30 inches decreased by a small but significant amount while the tension at 30 inches did not change; when it is realized that water is infiltrating into an already wet profile (average tension of $220 \mathrm{~cm}$ of water) and not a "dry" homogeneous soil, such behavior may be expected. Similar results have been reported by Burrows and Kirkham [1958]. (The water content-tension relations necessary for this behavior will be discussed later in light of capillary conductivity values calculated for various depths within the Panoche profile.) After 20 hours the tensions have decreased substantially at all depths. This is true after 24 hours when 4.8 inches of water have entered the surface with some of the applied water already passing the 60 -inch depth.

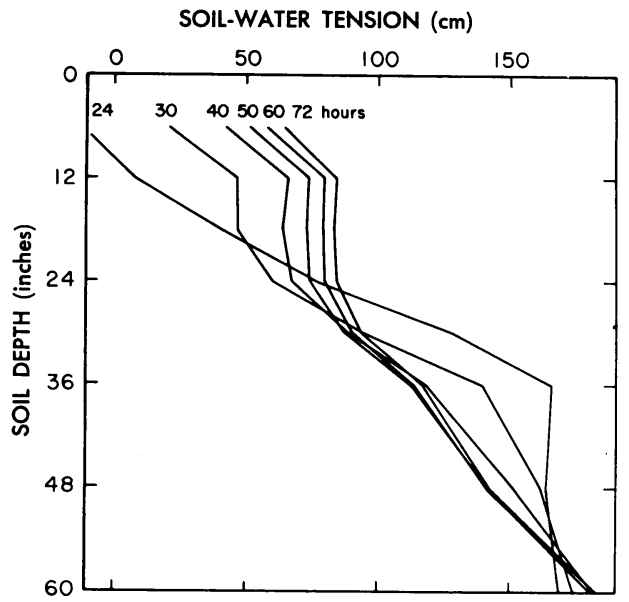

Fig. 3. Soil-water tension ( $\mathrm{cm}$ of water) versus soil depth, measured at commencement of drainage (24 hours) and at $30,40,50,60$ and 72 hours.

Figure 3 shows tension distributions for the first 2 days of the drainage period corresponding to 24 to 72 hours. For comparison, the distribution at 24 hours given in figure 2 has been included in the present figure. The most striking feature about the distributions is that tensions near the soil surface increase, while those of the greater depths decrease during the first few hours of drainage. The tension at the 30 -inch depth reached a minimum of $88 \mathrm{~cm}$ of water at 50 hours, or 26 hours after infiltration ceased. At the 60 -inch depth, tension originally at $250 \mathrm{~cm}$ of water was never reduced below $175 \mathrm{~cm}$.

Figure 4 shows additional tension distributions for greater drainage periods. A comparison of the tensions between the 6 and 12-inch depths reveals 
that the polyethylene film covering the soil surface apparently prevented evaporation. Somewhat greater changes in tension were measured near the soil surface compared to those deeper in the profile-this is because soil at the greater depths not only loses water but allows the additional water draining from soil above to pass through it.

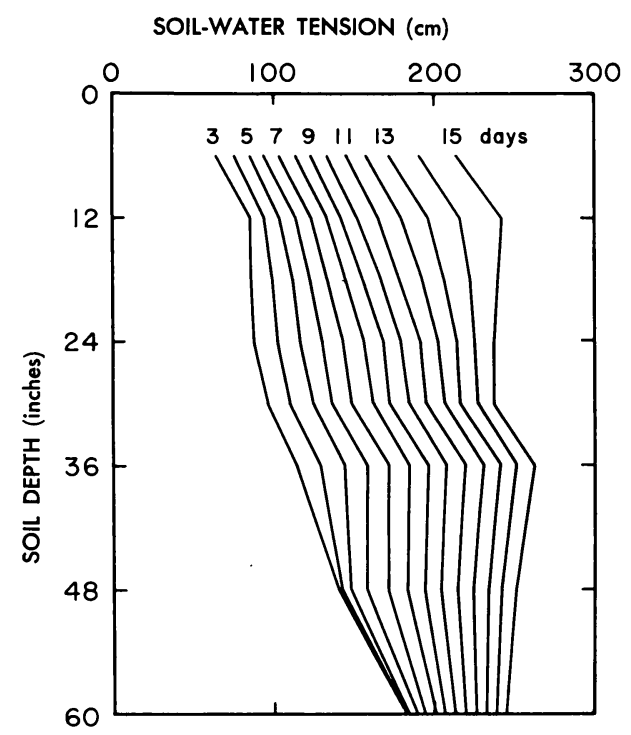

Fig. 4. Soil-water tension ( $\mathrm{cm}$ of water) versus soil depth, measured during drainage 3 , $4,5,6,7,8,9,10,11,12,13,14$ and 15 days after commencement of infiltration.

Soil-water contents were measured indirectly through tensiometer readings in the field plot that were related to soil characteristics of the soil cores removed from the field and measured in the laboratory. Although this method has the disadvantages of not measuring the water directly, it allows the soil water content of a small volume of soil to be ascertained.

Soil-water contents were measured directly by neutron scattering. Although this method of measurement is rapid and nondestructive it is not without some limitation, owing to the large sample size that includes the water content above and below the desired depth [McHenry, 1963]. Changes in water content at the same depth during known time-intervals are measured more accurately than absolute magnitudes of the total water content. Thus, the neutron method of measuring soil water was used in this experiment primarily to monitor changes in soil-water contents and, hence, water movement through the profile.

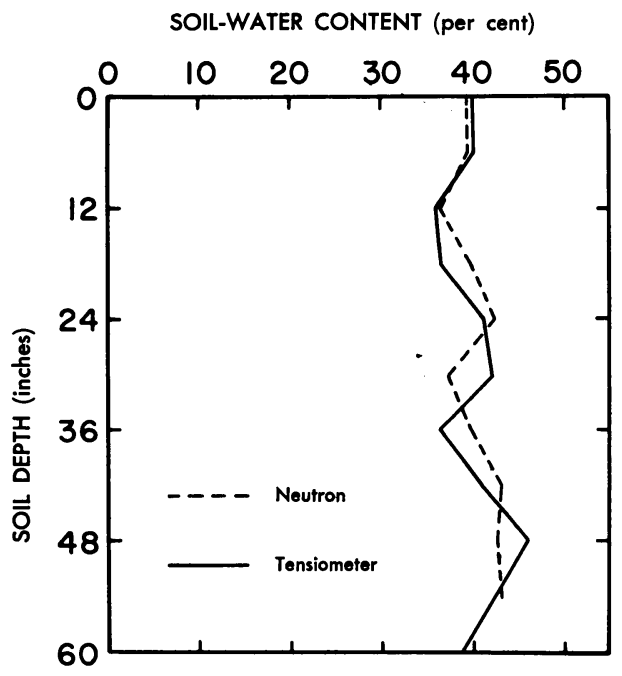

Fig. 5. Comparison of soil-water content versus soil depth, measured by neutron scattering and inferred from tensiometer measurements.

Figure 5 shows a comparison of the measurements of the tensiometer and the neutron methods for measuring soil water. Agreement between the two methods is satisfactory considering the lack of accuracy of the neutron method in the presence of an irregular vertical distribution of soil water. (Values of soil-water content given in succeeding figures will be derived from the tensiometric method.) Figure 6 shows how water movement within the profile during the 24-hour infiltration period may be perceived by observing changes in water content percentages.

During the first 5 hours of infiltration the water content in the top 12 inches of the profile increases rapidly and remains nearly constant for the remainder of the wetting period. The 18 and 24-inch depths wet more slowly. 
SOIL-WATER CONTENT (per cent)
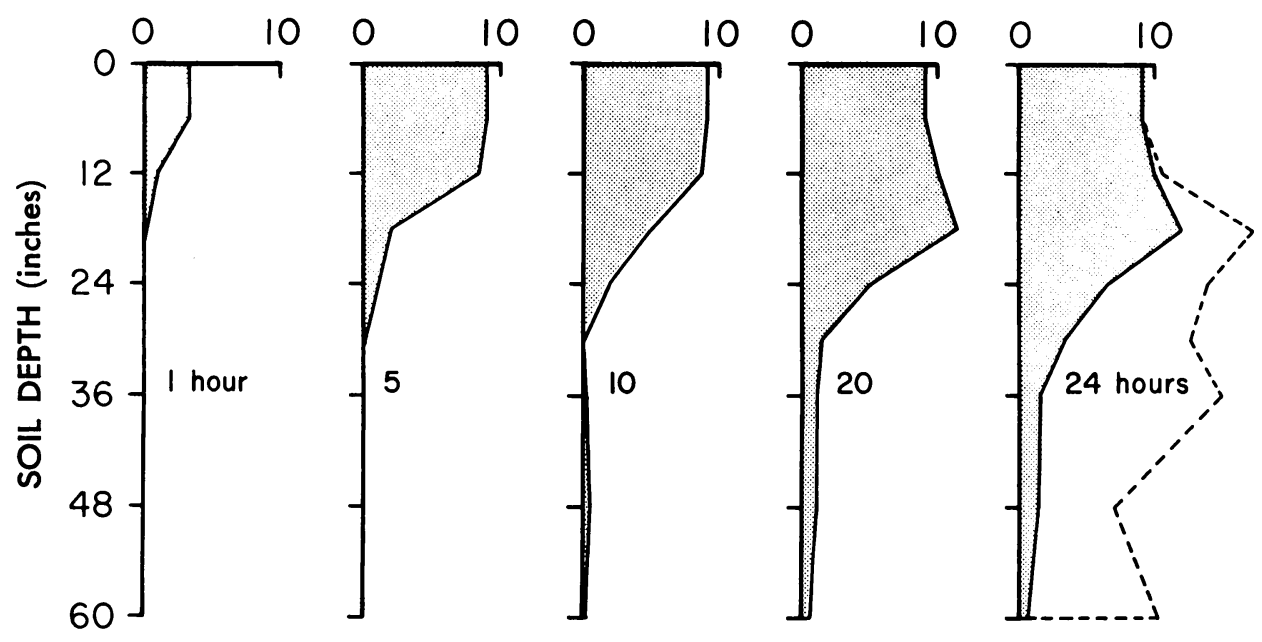

\section{INFILTRATION}

Fig. 6. Increase in soil-water content versus depth during 24-hour infiltration period. Zero on the abscissa refers to water content of the soil profile at commencement of infiltration. Initial values were $34.2,30.6,27.4,33.9,37.2,32.7,44.3$, and 38.2 per cent at the $6,12,18,24,30,36,48$, and 60 -inch depths, respectively. Broken line indicates increase in water content needed to saturate the profile.

with the former having the greater increase in soil water after 24 hours of infiltration. Note that the water contents below 30 inches increase before the water content at that depth changes; this behavior is indicated by tension data in figure 2 .

After 24 hours of infiltration the soil profile was water saturated to a depth of 6 inches; the broken line in the righthand graph of figure 6 represents water saturation. Measurements of infiltration velocity at this time were almost constant at 1.8 inches per day. If it is assumed that steady state existed at this time, it may be inferred from the last profile in figure 6 that the soil layer governing rate of entry was the 6 to 12-inch depth. Such an inference is based on calculations by Takagi [1960], who showed that unsaturated flow must exist in or at the bottom of the least permeable layer.

Figures 7 and 8 show redistribution of the applied water within the profile after infiltration. In figure 7 , the lefthand graph (24 hours) is the same as that given at the right-hand side of figure 6. During the first 48 hours of drainage (24 hours to 72 hours in figure 7) the water contents in the top 18 inches of the profile substantially decrease while those between the 18 to 48-inch depths generally increase; magnitudes of water content at the 48 and 60 -inch depths vary 2 per cent or less throughout the experiment. These soil layers allow water to pass out of the profile during infiltration and subsequent drainage, even though water contents of the layers remain nearly constant.

The soil profile continues to lose water significantly during the second week of drainage. By the fifteenth day of the experiment the water contents are equal to or less than those previous to infiltration. Figure 9 shows the rate at which water drains from the 60 -inch profile; here the water flux across the 60 -inch depth is plotted against the number of days after infiltration ceased. During the first 2 days of drainage the rate decreases rapidly from a value greater 
SOIL-WATER CONTENT (per cent)
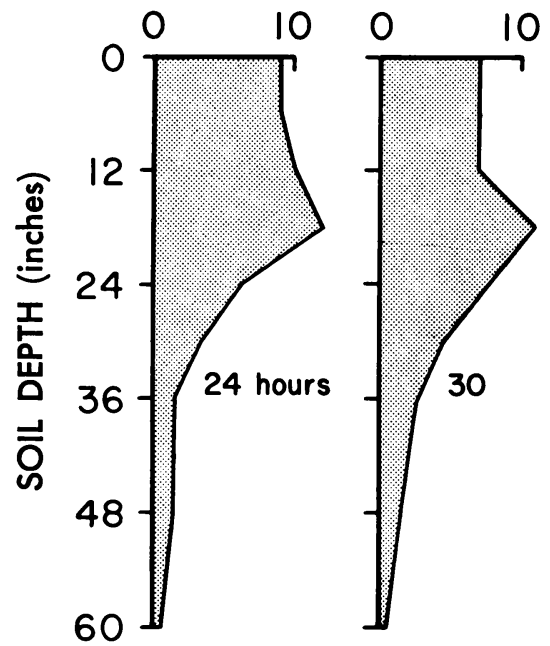
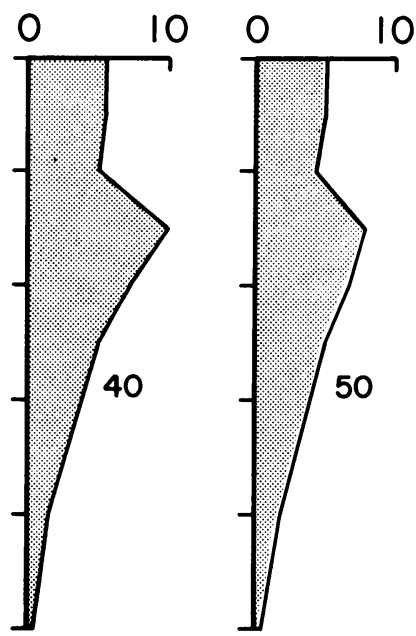

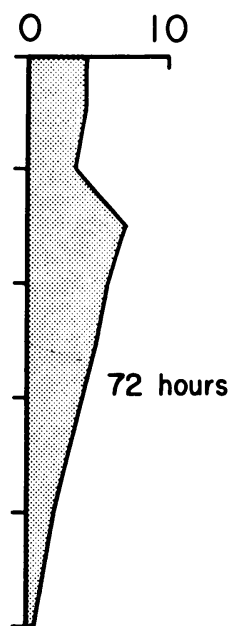

\section{DRAINAGE}

Fig. 7. Changes in soil-water content versus depth at commencement of drainage (24 hours) and for 72 hours after initiation of infiltration ( 48 hours drainage). Zero on the abscissa refers to water content of the soil profile at commencement of infiltration. Initial values were 34.2 $30.6,27.4,33.9,37.2,32.7,44.3$, and 38.2 per cent at the $6,12,18,24,30,36$, 48, and 60 -inch depths, respectively.

SOIL-WATER CONTENT (per cent)

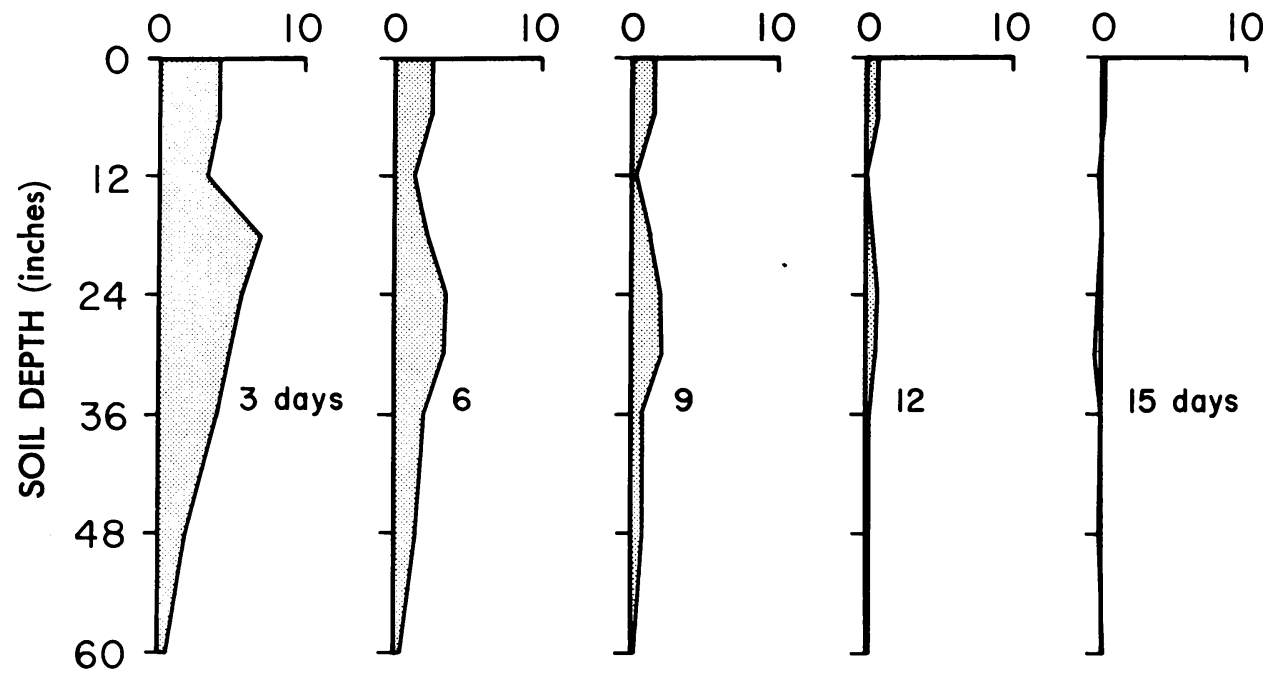

\section{DRAINAGE}

Fig. 8. Changes in soil-water content versus depth during drainage for 3 days (2 days after commencement of drainage) and 6, 9, 12 and 15 days. Zero on the abscissa refers to water content of the soil profile at commencement of infiltration. Initial values were $34.2,30.6,27.4,33.9,37.2$, $32.7,44.3$, and 38.2 per cent at the $6,12,18,24,30,36,48$, and 60 -inch depths, respectively. 
than 1 inch per day to less than 0.4 inch per day. Water continues to leave the profile at a rate gradually diminishing to 0.1 inch per day by the fifteenth day. Thus, the rate of downward movement has materially decreased after 2 days; however, during the subsequent 12 days more than 2 inches of water has left the profile.

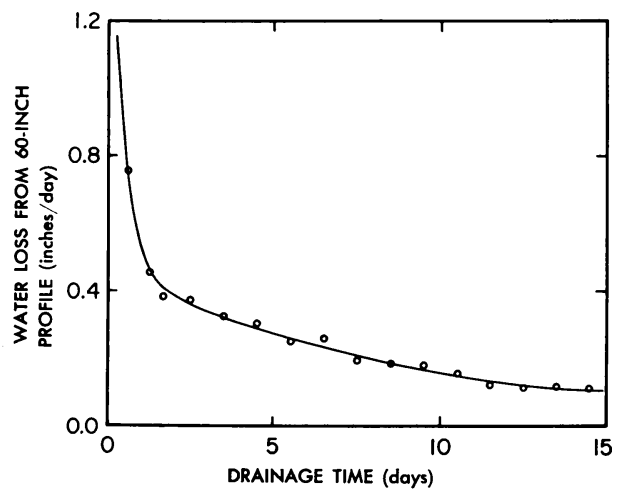

Fig. 9. Rate of water loss from the 60-inch profile of Panoche clay loam versus drainage time.

Figure 10 shows inches of water remaining within the 60 -inch profile above the 15-bar percentage versus the time since infiltration ceased. This stored water may be considered the plantavailable water if salinity effects are ignored, and the 15-bar percentage represents the permanent wilting percentage.

The capillary conductivity $\mathrm{K}$ defined by Darcy's Law

$$
v=-K \frac{d \varphi}{d x}
$$

was calculated for several depths within the profile with measurements of both soil water content and tension versus time. In this equation, $v$ represents the flux of water (cm per day), $x$ the vertical distance $(\mathrm{cm})$ and $\varphi$ the total potential head $(\mathrm{cm})$ equal to the sum of the soil-water tension and gravity head. Calculations were based on small timeintervals in order that potential gradient and the average water content of a soil layer could be considered constant. Figure 11 shows capillary conductivity versus soil-water content for seven depths. Data points represent calculated values for the majority of water contents existing during the experiment. Thus, the curves describing the capillary conductivity relations for the shallower depths cover a greater range of water content values than those for the greater depths. For each depth a

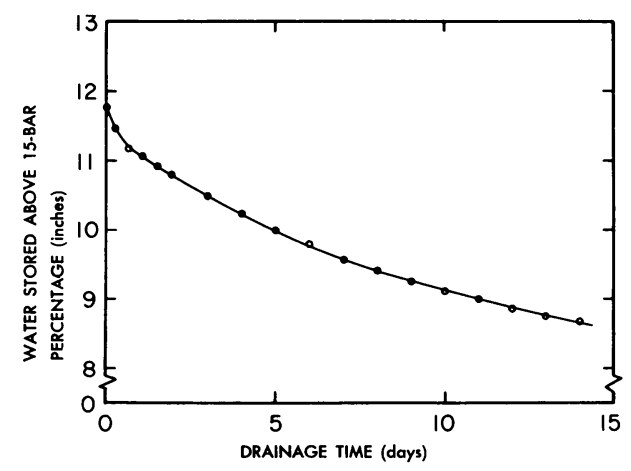

Fig. 10. The water content greater than the 15-bar percentage in the 60 -inch profile versus drainage time.

well-defined relation exists between $K$ and $\theta$. In general, the 6 to 12 -inch depth is less permeable than the 12 to 18 -inch and the 18 to 24 -inch depths, with the former being most permeable. The values of $K$ for depths between 24 and 60 inches are comparable, although the values of $K$ for the 48 to 60 -inch depth may possibly be smaller.

Many previous infiltration experiments, especially those conducted in the laboratory, have involved wetting a homogeneous soil that was initially airdry. Under such a condition the infiltrating water would have to increase the water content at each depth before passing into a greater soil depth. The soil in this experiment was not air-dry, and water passed through the 30 -inch depth during the initial stages of infiltration without increasing the soilwater content at that depth. With initial water content at the 30 -inch depth about 37 per cent, a capillary conductivity value greater than $0.1 \mathrm{~cm}$ per day is sufficient to transmit water from the shallower depths for the ob- 


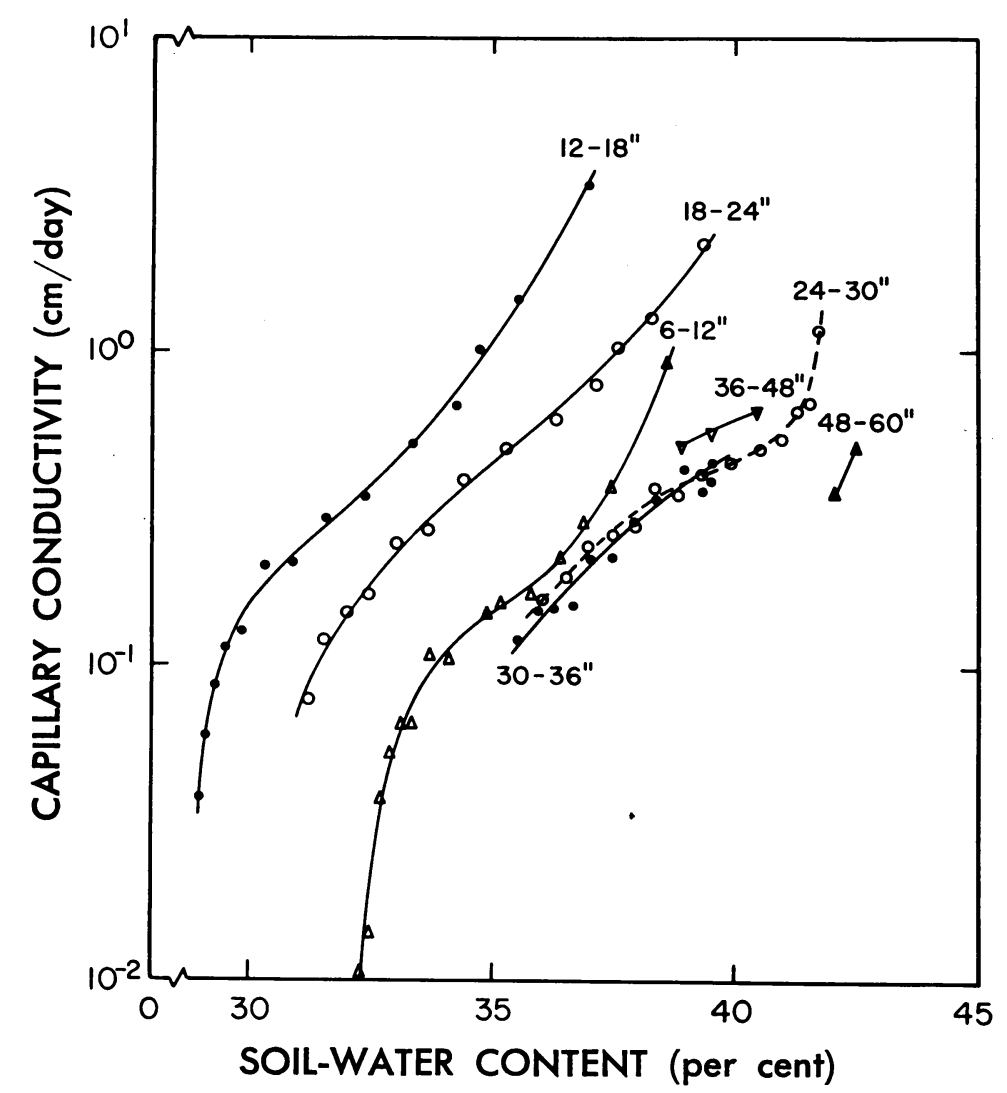

Fig. 11. Capillary conductivity versus soil-water content calculated from field measurements for 6 -inch intervals to a depth of 60 inches.

served tension distributions. For a later time-interval (between 30 and 72 hours), water draining from the 0 to 24-inch depth increases the water contents at greater depths, while the water content at the 30 -inch depth remains near 42 per cent. At this water content, capillary conductivity approaches $1 \mathrm{~cm}$ per day. With the prevailing tension distributions, the soil at this depth cannot lose water any faster than the rate at which it receives it from the overlying soil. After the water draining from the upper portion of the profile has diminished, the water content at the 30 -inch depth decreases readily. Thus, depending upon the heterogeneity of a soil profile and the existing soil water content-tension-capillary conductivity relations, water passing through a soil at a given location may result in either an increase or decrease in soil-water content.

Laboratory determinations of the soil characteristics of each depth provide a means of analyzing the above calculations of $K$ versus $\theta$. Figure 12 shows soil characteristics measured on the 3 inch core samples taken at the $6,24,36$ and 48-inch depths. Table 2 gives a complete summary for all depths of the soil-water content values measured for each applied tension. Figure 13 shows the relations between tension, water content and soil depth plotted as a three-dimensional diagram; the diagram shows a surface related to the capillary conductivity values given in figure 11 and provides an explanation of the soilwater movement illustrated in figures 6, 7 and 8. This type of diagram has been used previously to describe water 
TABLE 2

PER CENT SOIL-WATER CONTENT (VOIUME: BASIS) OF PANOCHE CIAY LOAM IN EQLILIBRILM WITH SEVERAL APPLIED TENSIONS

\begin{tabular}{|c|c|c|c|c|c|c|c|c|c|c|}
\hline \multirow{2}{*}{$\begin{array}{c}\text { Soil } \\
\text { depth }\end{array}$} & \multicolumn{10}{|c|}{ Applied tension ${ }^{*}(\mathrm{~cm}$ of water) } \\
\hline & 2 & 17 & 32 & 47 & 62 & 82 & 102 & 122 & 152 & 333 \\
\hline inches & \multicolumn{10}{|c|}{ per cent } \\
\hline $6 \ldots \ldots \ldots$ & 43.1 & 41.8 & 40.5 & 39.5 & 38.7 & 37.5 & 36.5 & 35.7 & 34.8 & 34.2 \\
\hline $12 \ldots \ldots \ldots \ldots$ & 41.1 & 40.0 & 38.7 & 37.4 & 36.0 & 34.2 & 32.6 & 31.5 & 30.4 & 30.0 \\
\hline $18 \ldots \ldots$ & 44.4 & 42.7 & 40.5 & 38.4 & 36.5 & 34.1 & 32.2 & 30.7 & 29.2 & 26.7 \\
\hline $24 \ldots$ & 47.8 & 46.1 & 44.4 & 43.0 & 41.7 & 40.1 & 38.9 & 37.8 & 36.7 & 30.8 \\
\hline $30 \ldots$ & 49.8 & 48.0 & 46.4 & 45.0 & 43.9 & 42.6 & 41.7 & 410 & 40.3 & 39.4 \\
\hline $36 \ldots$ & 47.4 & 46.5 & 45.2 & 43.3 & 41.4 & 39.2 & 37.5 & 36.3 & 34.8 & 31.5 \\
\hline 42. & 52.6 & 51.3 & 50.1 & 49.2 & 48.4 & 47.5 & 46.9 & 46.4 & 45.8 & 38.0 \\
\hline $48 \ldots$ & 51.3 & 50.2 & 49.4 & 48.7 & 48.1 & 47.4 & 46.9 & 46.5 & 46.0 & 42.2 \\
\hline $54 \ldots \ldots$ & 52.6 & 51.3 & 50.3 & 49.3 & 48.5 & 47.7 & 47.0 & 46.5 & 45.9 & 37.5 \\
\hline $60 \ldots \ldots \ldots$ & 48.4 & 47.5 & 46.8 & 46.1 & 45.2 & 43.5 & 42,1 & 40.9 & 396 & 38.0 \\
\hline
\end{tabular}

-Values represent the mean of three determinations made on 3 " $\times 3$ " soil cores.

movement through several field soils [Nielsen et al., 1961].

Figure 13 shows that at about the 12 to 18-inch depth there is a suppression corresponding to smaller water contents than those at the 6 to 12 -inch and the 18 to 24-inch depths. This suppression indicates larger pores, while the ridge on either side of it indicates smaller pores. Hence, highest capillary conductivities should be observed at the 12 to 18-inch depth, and figure 11 shows that this is true. For the greater depths, where values of capillary conductivity were lower than those for depths nearer the surface, a greater water content retention is observed (fig. 13). The rather severe suppression observed at the 36 -

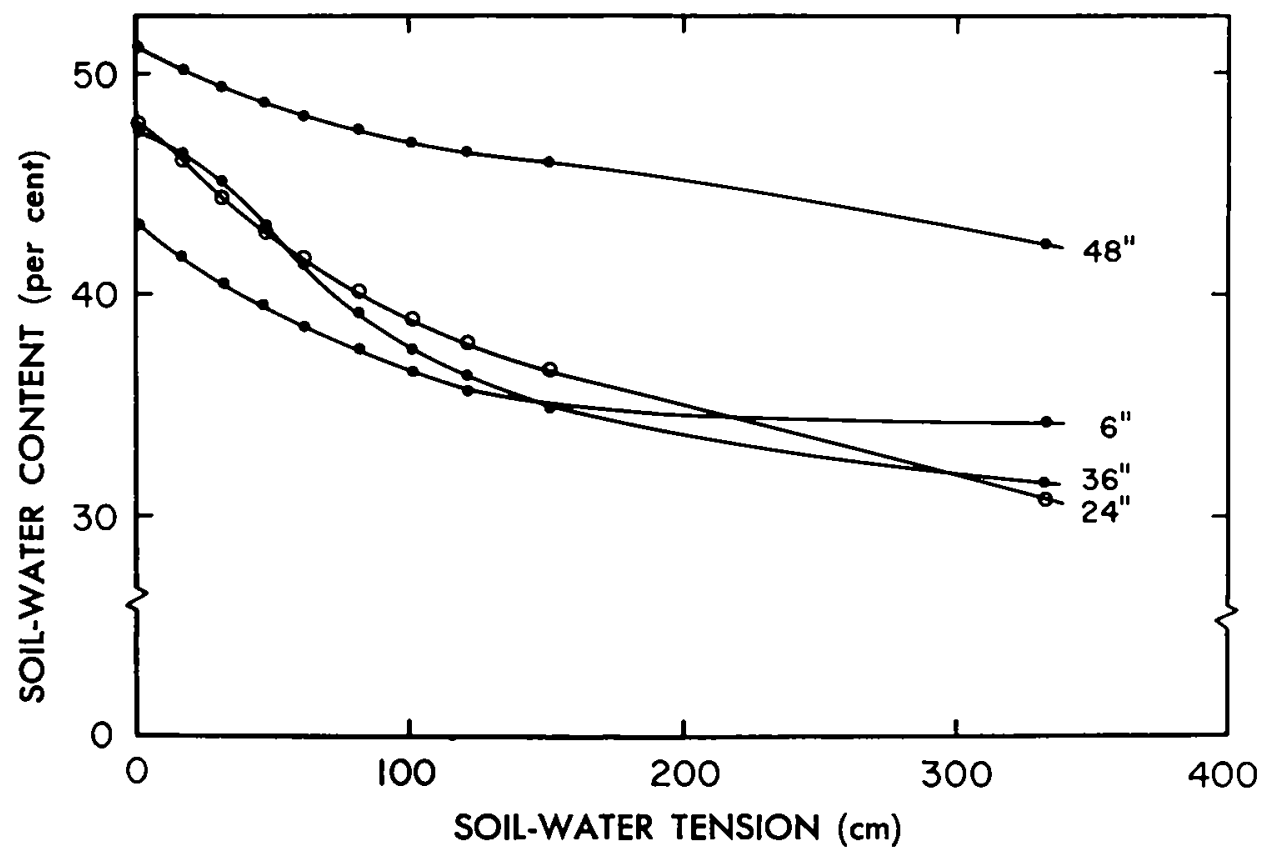

Fig. 12. Soil-water characteristic curves for the $6,24,36,48$-inch deptlis of Panoche clay loam soil determined on $3 \times 3$-inch core samples. 


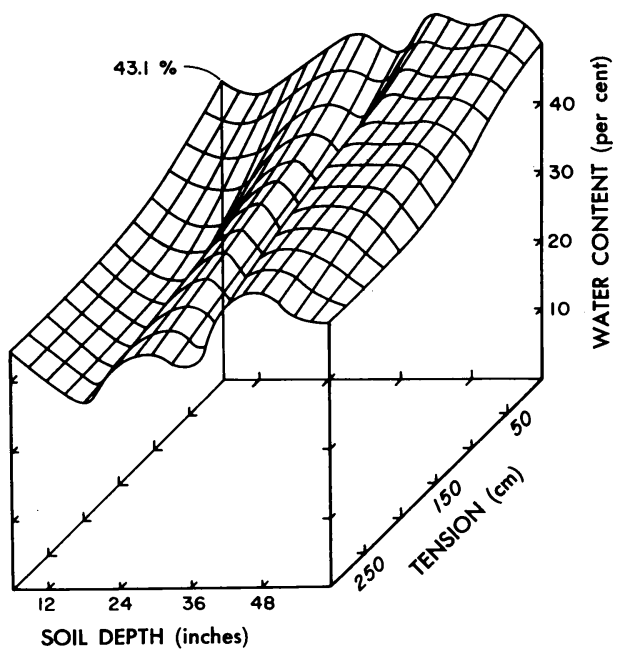

Fig. 13. Three-dimensional diagram of water content, soil-water tension (cm of water) and depth for Panoche clay loam. inch depth in figure 13 is not reflected in the capillary conductivity values for the 30 to 36 -inch or the 36 to 48 -inch depths. The smaller pores occurring at the 30-inch depth and the 48-inch depth probably dominate the flow characteristics for both of the above layers.

Although soil-water tensions greater than $300 \mathrm{~cm}$ of water were not measured in this experiment, it may be of interest to further identify the Panoche clay loam by examining larger tensions and smaller water contents than those given in table 2. Table 3 gives soil water contents corresponding to $0.5,1.0,2.0,5.0$ and 15.0 bars pressure applied to sieved samples. A comparison of these values with those presented in table 3 reveals some discrepancies which probably result from the use of sieved samples instead of soil cores.

\section{DISCUSSION}

It appears from this study, and others cited, that the amount of water stored in a profile and available for plant growth is not constant and is difficult to ascertain or predict at any specified time. For example, 4 inches of water was lost from the 60-inch Panoche profile during a 2-week period without evapo-transpiration. Had evaporation taken place, the loss would have been greater. Initial water content and the depth of wetting has also been shown to influence the rate of downward water movement [Baver, 1936; Colman, 1944; Smith and Browning, 1947]. The presence of an actively-growing crop may decrease or increase the amount of water lost by deep percolation, depending upon the rooting depth of the crop and the quantity of water applied [Robins, et al., 1954].

TABLE 3

PER CENT SOIL-WATER CONTENT (WEIGHT BASIS) OF PANOCHE CLAY LOAM IN EQUILIBRIUM WITH SEVERAL APPLIED PRESSURES

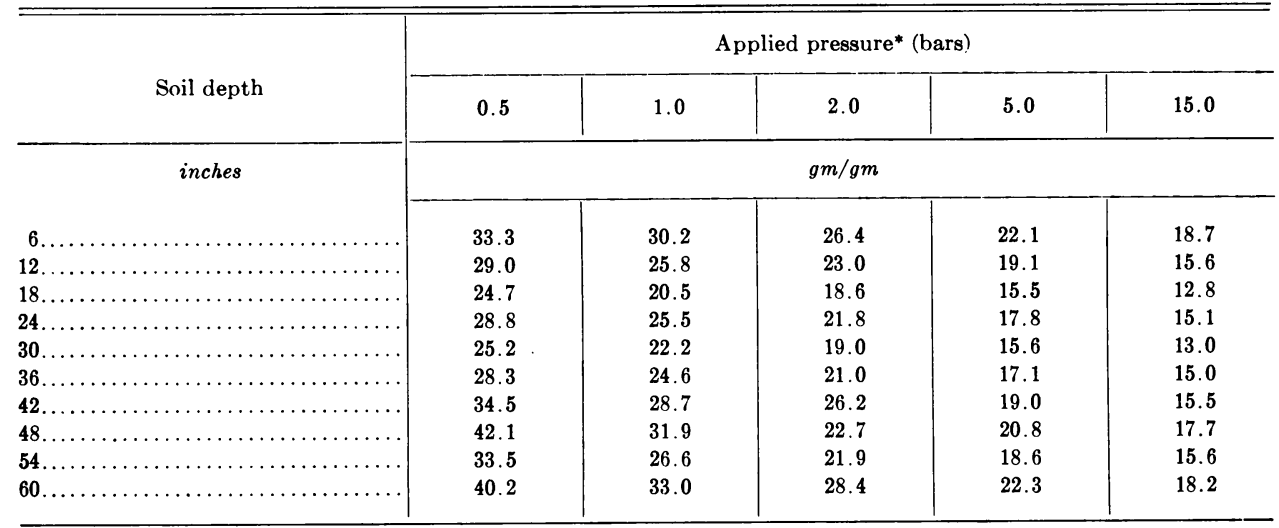

* Values given represent the mean of two determinations made on samples passed through a $2 \mathrm{~mm}$ sieve. 
Growers in the vicinity of the West Side Field Station have found it necessary to pre-irrigate during winter and early spring to insure an adequate supply of water during hot, dry summer months. In addition to the increased supply of water available to plants, another equally important benefit is derived through pre-irrigation-a favorable salt balance within the profile. The water lost from the Panoche soil after a heavy irrigation drains out of the profile slowly and at water contents considerably less than the saturation point-two conditions that enhance the efficiency of salt removal [Biggar and Nielsen, 1962; Wilson, et al., 1961]. Thus, frequency and time of irrigation often should be based not only upon the need for replenishing and storing the soil water, but upon the need for efficient leaching of excess salts accumulated from summer-applied irrigation water. During brief time-intervals when salt balance may not be of prime concern, the frequency and rate of water application for each irrigation should allow a soil-water distribution within the profile for optimum plant growth.

Field experiments concerned with soil-water-plant relationships generally entail several irrigation treatments. Although the method of water application (including frequency and quantity of water added) is usually specified, the plant-water relations are ascertained through measurement of soil-water content or tension, or both, with soil depth and time. These measurements yield values of the average tension or per cent of available water in the root zone during critical periods of crop growth. The measurements are also used to calculate water absorbed by the crop or water lost through deep percolation; for these calculations, numerical values of the capillary conductivity for each soil depth are required, and methods for determining soil conductivity $K$ are given by Butijn and Wesseling [1959], Gardner [1956], Gardner and Miklich [1962], Kunze and Kirkham [1962], Miller and Elrick [1958], Richards and Richards [1962], Richards and Weeks [1953], and Rijtema [1959]. Although uniformly-packed soil samples have been analyzed under controlled temperature conditions, the reliability of calculated values of $K$ determined by the methods referred to above have oftentimes been questionable. Values obtained for soil cores removed from the field are frequently erratic owing (among other causes) to small sample sizes.

Capillary conductivity values may be easily calculated from field data, provided frequent water-content relation measurements are made. Field determinations made in this investigation do not involve small samples or the shortcomings of simplified mathematical procedures for calculating $K$ from shortlived transient data measured in the laboratory. Rather, the calculations given are based on steady-state flow conditions for relatively large areas with each soil horizon in its original and undisturbed position. Within a 2-week interval, capillary conductivity relations were obtained for seven depths including a wide range of soil water contents. To obtain as many datum points with laboratory methods would have involved considerably more time with less reliability. The principal disadvantages of the field determination are the small range in water contents obtained at the greater depths, and the fact that values of $K$ are restricted to soil-water contents for tensions less than $500 \mathrm{~cm}$ of water-which is the useful range of the common tensiometer. 
BAVER, L. D.

\section{LITERATURE CITED}

1936. Soil characteristics influencing the movement and balance of soil moisture. Soil Sei. Soc. Am. Proc. 1:431-37.

BIGGAR, J. W., and D. R. NIELSEN

1962. Miscible displacement: II. Behavior of tracers. Soil Sci. Soc. Am. Proc. 26:125-28.

Bouyoucos, G. J.

1951. A recalibration of the hydrometer method for making mechanical analysis of soils. J. Am. Soc. Agron. 43:434-39.

Burrows, W. C., and D. KirKHAM

1958. Measurement of field capacity with a neutron meter. Soil Sci. Soc. Am. Proc. 22:103-05.

ButiJn, J., and J. WESSELING

1959. Determination of the capillary conductivity of soils at low moisture tensions. Netherlands Jour. Agr. Sei. 7:155-63.

Cannell, G. H., and L. H. Stolzy

1962. Hydraulic gradients associated with infiltration in field studies. Soil Sci. Soc. Am. Proc. 26:112-14.

Colman, E. A.

1944. The dependence of field capacity upon the depth of wetting of field soils. Soil Sci. 58:43-50.

EdLefsen, N. E., and G. B. Bodman

1941. Field measurements of water movement through a silt loam soil. J. Am. Soc. Agron. 33:713-31.

GARDNER, W. R.

1956. Calculation of capillary conductivity from pressure outflow data. Soil Sci. Soc. Am. Proc. 20:317-20.

GARDNER, W. R., and F. J. MiKLICH

1962. Unsaturated conductivity and diffusivity measurements by a constant flux method. Soil Sci. 93:271-74.

Green, R. E., R. J. HaNks, and W. E. Larson

1964. Estimates of field infiltration by numerical solution of the moisture flow equation. Soil Sci. Soc. Am. Proc. (in press).

Haise, H. R., H. J. HaAs, and L. R. Jensen

1955. Soil moisture studies of some Great Plains Soils: II. Field capacity as related to $1 / 3$ atmosphere percentage, and "minimum point" as related to 15- and 26-atmosphere percentages. Soil Sci. Soc. Am. Proc. 19:20-25.

ISRAELSEN, $\mathrm{O}$. W.

1918. Studies on capacities of soils for irrigation water, and on a new method of determining volume weight. J. Agr. Research 13:1-37.

ISRAELSEN, O. W., and F. L. WeST

1922. Water-holding capacity of irrigated soils. Utah. Agr. Expt. Station Bulletin 183. 24 pages.

Kunze, R. J., and D. KIRKhAM

1962. Simplified accounting for membrane impedance in capillary conductivity determinations. Soil Sci. Soc. Am. Proc. 26:421-26.

McHenry, J. R.

1963. Theory and application of neutron scattering to the measurement of soil moisture. Soil Sei. 95:294-307.

Marshall, T. J., and G. G. Stirk

1949. Pressure potential of water moving downward into soil. Soil Sci. 68:359-70.

Miller, D. E., and W. C. Bunger

1963. Moisture retention by soil with coarse layers in the profile. Soil Sci. Soc. Am. Proc. 27: (in press).

MiLler, E. E., and D. E. ElRick

1958. Dynamic determination of capillary conductivity extended for non-negligible membrane impedance. Soil Sci. Soc. Am. Proc. 22:483-86.

NiElsen, D. R., and R. E. Phillips

1958. Small fritted glass bead plates for determination of moisture retention. Soil Sci. Soc. Am. Proc. 22:574-75. 
Nielsen, D. R., D. Kirkham, and W. R. VAN WiJK

1959. Measuring water stored temporarily above the field moisture capacity. Soil Sci. Soc. Am. Proc. 23:408-12.

1961. Diffusion equation calculations of field soil water infiltration profiles. Soil Sci. Soc. Am. Proc. 25:165-68.

Ogata, G., and L. A. RICHaRds

1957. Water content changes following irrigation of bare-field soil that is protected from evaporation. Soil Sci. Soc. Am. Proc. 21:355-56.

Philip, J. R.

1955. Numerical solution of equations of the diffusion type with diffusivity concentrationdependent. Trans. Faraday Soc. 51:885-92.

1957. Numerical solution of equations of the diffusion type with diffusivity concentrationdependent. II. Australian Jour. Physics 10:29-42.

Richards, L. A.

1947. Pressure membrane apparatus, construction, and use. Agr. Eng. 28:451-54.

1949. Methods for mounting porous plates used in soil moisture measurements. J. Am. Soc. Agron. 41:487-90.

1954. Multiple tensiometer for determining the vertical component of the hydraulic gradient in soil. Soil Sci. Soc. Am. Proc. 18:7-10.

Richards, L. A., W. R. Gardner, and G. Ogata

1956. Physical processes determining water loss from soil. Soil Sci. Soc. Am. Proc. 20: 310-14.

RICHARDS, L. A., and O. R. NEAL

1936. Some field observations with tensiometers. Soil Sci. Soc. Am. Proc. 1:71-92.

RichaRds, L. A., and P. L. Richards

1962. Radical flow cell for soil water measurement. Soil Sci. Soc. Am. Proc. 26:515-18.

RichaRds, S. J., and L. V. WeEks

1953. Capillary conductivity values from moisture yield and tension measurements on soil columns. Soil Sci. Soc. Am. Proc. 17:206-09.

RiJtema, P. E.

1959. Calculation of capillary conductivity from pressure plate outflow data with nonnegligible membrane impedance. Netherlands Jour. Agr. Sci. 7:209-15.

Robins, J. S., W. O. PruitT, and W. H. GARDNER

1954. Unsaturated flow of water in field soils and its effect on soil moisture investigations. Soil Sci. Soc. Am. Proc. 18:344-47.

Scofield, C. S., and C. C. WRIGHT

1928. The water relations of Yakima Valley soil. J. Agr. Research 37:65-85.

Smith, R. M., and D. R. Browning

1947. Soil moisture tension and pore space relations for several soils in the range of the TAKAGI, S. "field capacity." Soil Sci. Soc. Am. Proc. 12:17-21.

1960. Analysis of the vertical downward flow of water through a two-layered soil. Soil Sci. 90:98-103.

Wilson, L. G., J. N. Luthin, and J. W. BigGAR

1961. Drainage-salinity investigation of the Tulelake lease lands. Calif. Agr. Expt. Sta. Bul. 779 . 


\section{APPENDIX}

A detailed soil map was made of the West Side Field Station in September 1960. This survey consisted of a number of auger borings to a depth of 4 feet. Soil texture was determined by feel in the field at foot-depth intervals.

Only one soil series-the Panoche series-was found on the station. A description of this series is as follows.

Panoche silty clay loam:

Ap 0-4" light brownish gray (2.5Y 6/2 dry) silty clay loam; massive but breaking to a subangular blocky structure; many fine pores; hard when dry, friable when moist, and slightly sticky when wet; mildly alkaline and slightly calcareous.

AC 4-20" similar to the horizon above except this horizon is moderately alkaline and more calcareous; also, this horizon is more compact and dense than the horizons above and below.

$\mathrm{C}_{1}$ 20-33" light olive brown (2.5Y 5/4 dry) silty clay loam; massive but breaks readily to a subangular blocky structure; very porous; hard when dry, friable when moist, and slightly sticky when wet; moderately alkaline; thin seams of segregated lime.

$\mathrm{C}_{2} \quad 33-60^{\prime \prime}+$ similar to the horizon but has loam near silt loam texture with some evidence of stratification.

(Reported by K. D. Gowans, Department of Soils and Plant Nutrition.) 
The journal HILGARDIA is published at irregular intervals, in volumes of about 650 to 700 pages. The number of issues per volume varies.

Single copies of any issue may be obtained free, as long as the supply lasts; please request by volume and issue number from:

\author{
Agricultural Publications \\ University Hall \\ University of California \\ Berkeley, California 94720
}

The limit to nonresidents of California is 10 separate titles. The limit to California residents is 20 separate titles.

The journal will be sent regularly to libraries, schools, or institutions in one of the following ways:

1. In exchange for similar published material on research.

2. As a gift to qualified repository libraries only.

3. On a subscription basis $-\$ 7.50$ a year paid in advance. All subscriptions will be started with the first number issued during a calendar year. Subscribers starting during any given year will be sent back numbers to the first of that year and will be billed for the ensuing year the following January. Make checks or money orders payable to The Regents of The University of California; send payment with order to Agricultural Publications at above address. 